\title{
LIQUEFIED NATURAL GAS INFRASTRUCTURE AND PROSPECTS FOR THE USE OF LNG IN THE BALTIC STATES AND FINLAND
}

\author{
J. Savickis' ${ }^{1}$ L. Zemite'2, L. Jansons², N. Zeltins², I. Bode², \\ A. Ansone ${ }^{2}$, A. Selickis ${ }^{2}$, A. Broks' ${ }^{2}$ A. Koposovs ${ }^{2}$ \\ ${ }^{1}$ ITERA Latvija \\ 50 Skanstes Str., Riga, LV-1013, LATVIA \\ ${ }^{2}$ Riga Technical University, \\ Faculty of Electrical and Environmental Engineering, \\ Institute of Power Engineering \\ 12-1 Azenes Str., Riga, LV-1048, LATVIA \\ *e-mail: laila.zemite@rtu.Iv
}

In the early 2010 s, only 23 countries had access to the liquefied natural gas (hereinafter LNG). Import terminals, despite attractive short-term economics, took long time to build, and rigid supply contracts made truly global use of LNG rather complicated. Concerns about geopolitical risks also stunted demand growth from existing supply sources, even when new LNG export routes and sources became available.

Current natural gas market is very different, both in terms of market participants and accessibility and diversity of services. In 2019, the number of LNG importing countries reached 43. Rising competition among suppliers and increasing liquidity of markets themselves created favourable conditions to diversify contract duration, size, and flexibility. In addition, development of floating storage and regasification unit (hereinafter - FSRU) technology provided LNG suppliers with a quick response option to sudden demand fluctuations in regional and local natural gas markets [1].

Moreover, LNG is one of the major options not only for bringing the natural gas to regions where its pipeline supply infrastructure is historically absent, limited or underdeveloped, but also for diversification of the natural gas supply routes and sources in regions with sufficient state of pipeline delivery possibilities. And it concerns smaller natural gas markets, like the Baltic States and Finland as well. Accordingly, prospects for use of LNG there in both mid and long-term perspective must be carefully evaluated, especially in regards to emerging bunkering business in the Baltic Sea aquatory and energy transition in Finland, replacing coal base-load generation with other, more sustainable and environmentally friendly alternatives.

Keywords: Bunkering, Finland, LNG, LNG infrastructure, natural gas, the Baltic States. 
LNG is the natural gas that has been cooled to a liquid state, at about $-260^{\circ}$ Fahrenheit, for shipment, distribution and storage. The volume of the natural gas in liquid state is about 600 times less than its volume in the gaseous state [2], [3]. Thus, process of liquefaction makes possible to transport the natural gas to significant distances - different continents and parts of the globe, or simply places, which pipeline infrastructure does not reach. Markets that are too far away from producing regions to be connected directly to them via pipeline infrastructure have access to the natural gas exclusively because of LNG.

For large-volume transportation, LNG is loaded onto double-hulled carrier ships, which are used for both safety and insulating purposes. Once the carrier arrives at the receiving port, LNG is off-loaded into storage tanks or regasified for injection into a pipeline distribution network [4]. LNG can also be shipped in smaller quantities, usually over shorter distances and used as a bunkering fuel. There is also a growing segment of very small-scale LNG shipments, which are usually performed by using the same containers as used on trucks in international trade, specially outfitted with cryogenic tanks [5]. Other small-scale LNG activities include peak demand response liquefaction and storage facilities, which can hold the natural gas compactly for periods of high demand. In some regions, particularly, in the US and Canada, LNG is also brought by truck to and from these facilities.

In 2020, there were 29 large-scale LNG import terminals in operation in Europe. Twenty-one of them are located in the current Member States of the European Union (hereinafter - EU) - and therefore subject to the EU regulation, three - in the UK and four - in the third countries (Turkey and the Russian Federation). Twenty-three are land-based LNG import terminals, five FSRUs, and one, located in Malta, is an import facility comprised of a floating storage unit and onshore regasification facility. Six terminals - South Hook, Dragon, Isle of Grain in the UK, Gate in the Netherlands, Rovigo in Italy and Dunkerque in France have been granted exemptions from the EU rules on regulated third party access [6].

Europe's increasing prominence in the global LNG market continued throughout 2018, 2019 and 2020. In 2018, its 15 LNG importing countries collectively held a $15.6 \%$ share of the total global LNG import market, demonstrating a $6.4 \%$ rise in comparison with results of 2017.

In 2019, the European LNG importers increased their global market share to $24.2 \%$, and the volume of LNG imported by $75.6 \%$. As a whole, the total amount of LNG imported by the EU Member States was more than 108 billion cubic meters (hereinafter - BCM). In comparison with 2018, the rise was rather significant - by 48BCM. The biggest LNG importers in the EU were: Spain with 22.4, France with 22.1, the UK with 18 , Italy with 13.5 , the Netherlands and Belgium with 8.6-8.8 BCM. As a result of increasing import volumes and decreasing average annual prices, the monetary value of the EU LNG imports in 2019 reached 16.2 billion euros (hereinafter - EUR), slightly up from EUR 15.4 billion in 2018 [6]. Qatar was the largest exporter of LNG to Europe, followed by the Russian Federation and the US.

Between 2017 and 2023, the global liquefied natural gas trade is expected to grow by more than $100 \mathrm{BCM}$, from 391 to $505 \mathrm{BCM}$, and large share of this growth 
is expected to be contributed by the US natural gas exporters. Moreover, shrinking percentage of the natural gas use in the EU Member States has not been an obstacle for the International Energy Agency to estimate that LNG imports to Europe in 2040, if compared to 2016 levels, should increase by almost $20 \%$ [7], because blend of the natural gas and renewables gases (hereinafter $-\mathrm{RG}$ ) is widely recognised as valid transitional fuel in a way to decarbonization of the EU's power generation and transportation sectors over the next three decades [8].

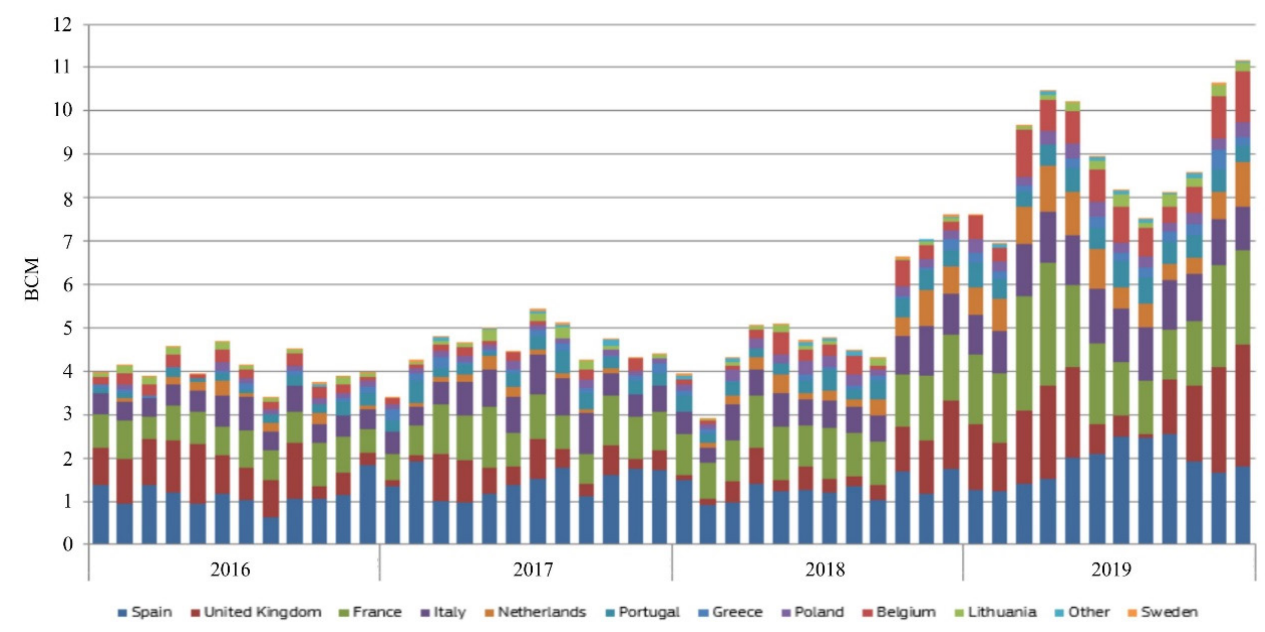

Fig. 1. The EU LNG import (by Member State, in BCM).

Source: EC calculations based on tanker movements reported by Thomson Reuters.

The major pathway to decarbonization of the EU's energy and transport - the European Green Deal - provides a framework for the EU's energy transition with the aim of achieving net-zero greenhouse gas (hereinafter-GHG) emissions by 2050 [9], [10]. The natural gas, including regasified LNG, is being regarded as suitable fuel for the energy transition - in light of its lower carbon intensity compared to heavier fossil fuels. The natural gas might prove not to be carbon neutral enough in a long term, but it is surely clean enough to play an important role in the European energy supply mix in the short and mid-term perspective. As for Europe's transition from fossil fuels such as coal and oil to renewable energy sources (hereinafter - RES), the natural gas can bridge a gap by providing a reliable, nonintermittent source of energy. Therefore, LNG serves to diversify sources and routes of the natural gas import to Europe.

While pipeline natural gas deliveries from Russia and Algeria, amongst others, will continue to supply a large proportion of the natural gas for the EU, with phasing out of coal and lignite-fired power generation and the continued decline of the domestic natural gas production, a growing share of LNG in the European primary energy mix is highly likely [6], especially, in such sectors as maritime and heavy-duty road transport, and power generation. 
Table 1. The Natural Gas Consumption in the Baltic States and Finland (TWh (BCM), 2017-2019)

\begin{tabular}{|l|c|c|c|}
\hline & \multicolumn{3}{|c|}{ TWh (BCM) } \\
\hline Estonia & $\mathbf{2 0 1 7}$ & $\mathbf{2 0 1 8}$ & $\mathbf{2 0 1 9}$ \\
\hline Latvia & $5.2(0.53)$ & $5.2(0.53)$ & $14.3(1.46)$ \\
\hline Lithuania & $13.1(1.34)$ & $15.1(1.55)$ & $23.6(2.42)$ \\
\hline Finland & $24.2(2.48)$ & $22.3(2.28)$ & $19.5(2)$ \\
\hline Total & $17.6(1.8)$ & $21.5(2.2)$ & $62.2(6.37)$ \\
\hline
\end{tabular}

Despite the fact that overall natural gas consumption in the Baltic and Finland is decreasing or standing still at best [11], the demand for the Baltic small-scale LNG market is projected to reach 1.908 million tonnes of LNG per annum (between 1.38 and $1.41 \mathrm{BCM}$ of the natural gas per annum) by 2030, actuating at an estimated compound annual growth rate of $14.01 \%$ from 2020 to 2030 . Some estimates show that increasing investment in LNG infrastructure and strong support from the local governments for adoption of LNG as a marine and road transport fuel are expected to give a significant push to an actual market growth in the Baltics in the nearest future [12].

As for infrastructure, the expected investment growth includes, but is not limited to, building of new LNG import terminals, bunkering points, truck fuelling stations, and, possibly, small-scale autonomous natural gas supply networks. Currently, the Baltic States and Finland have three operational LNG terminals, only one of which - Klaipeda LNG in Lithuania - is connected to the natural gas transport network. The second terminal of this kind Hamina LNG in the South-eastern part of Finland - is expected to be in full commercial operation in 2021.

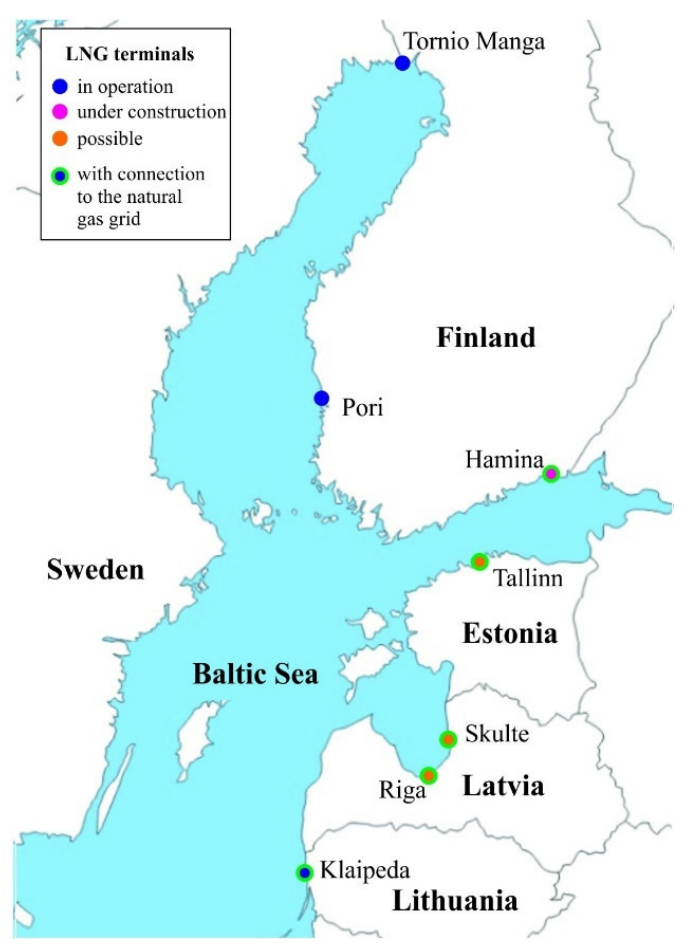

Fig. 2. LNG terminals in the Baltic States and Finland.

Klaipeda LNG terminal currently serves as a hub for LNG import in the north-eastern Baltics; however, with recent developments in Estonia and possible LNG projects in Latvia, at least partial relocation of LNG import traffic might take place by or shortly after 2030 [12]. 


\subsection{Lithuania}

As it has been mentioned before, the only Baltic State currently possessing LNG terminal is Lithuania. The geographically closest large-scale LNG terminal outside the Baltic States is Świnoujście LNG in Poland, but currently it cannot be part of the Baltic regional natural gas market because it is not yet connected to the Baltic-Finnish natural gas network.

Klaipeda LNG started its operation on 3 December 2014, and therefore Lithuania became the fifth country in the world to use FSRU technology for LNG imports. The central element of the Klaipeda LNG terminal - FSRU "Independence", the LNG carrier built by "Hyundai Heavy Industries", was leased from "Höegh LNG" for ten years with a possibility of buyout. It has a maximum import capacity of almost 4 billion cubic metres (hereinafter $-\mathrm{m}^{3}$ ) of the natural gas per annum (2.2 million tonnes of LNG), while it has four storage tanks with total capacity of $170.000 \mathrm{~m}^{3}$. The Lithuanian Parliament voted to operate its LNG import facility at least until 2044 and advised JSC Klaipedos Nafta to negotiate a purchase of the LNG regasification vessel in the late 2024 [13].

By the end of 2020, the total amount of loading and re-loading operations carried

\subsection{Latvia}

Currently, Latvia lacks any elements of the LNG import infrastructure, although several propositions to build a terminal in different locations were presented over the course of the last decade. The first proposition is related to Kundzinsala Southern Project, or more commonly known as Kundzinsala LNG terminal project. According out at Klaipeda LNG terminal reached 200. Since 2014, more than 80 TWh (terawatthours (hereinafter - TWh); $8.19 \mathrm{BCM}$ ) of the natural gas has been regasified and supplied to the Lithuania national natural gas grid from the terminal. Last year alone, $20 \mathrm{TWh}(2.05 \mathrm{BCM})$ of natural gas was regasified there, and, as a result, approximately $70 \%$ of the year's natural gas delivery in Lithuania was carried out through Klaipèda LNG terminal.

The year 2020 was particularly favourable for the American LNG imports to Europe, including the Baltics. Between 2016 and October 2020, 10 cargoes from the US were delivered to Lithuania, totalling 9.37 TWh (0.96 BCM) of LNG. Last year, LNG cargos from the US made up $37 \%$ of total LNG import of Klaipeda LNG terminal. About $49 \%$ of LNG was imported from Norway, but the rest - by small quantities only - from other sources.

However, in comparison, the US LNG deliveries to Lithuania between 2016 and 2020 corresponded to $0.5 \%$ of all its LNG export operations [7].

As for 2021, more than $14 \mathrm{TWh}$ $(1.43 \mathrm{BCM})$ of regasification capacity has already been ordered at Klaipeda LNG terminal.

to information of the Freeport of Riga, LNG terminal with an area of 34 hectares was planned to be built on the island of Kundzinsala - the largest island in the Daugava River in Riga, which is mainly used as a maritime trade related industrial area. Instead of planning connection to the natural gas transmission network, developers of 
Kundzinsala LNG terminal made a decision in favour of connection to the natural gas distribution grid. The geographical location of the terminal was a reason why its connection to the natural gas transmission network was not regarded as economically and technically feasible. Project team requested and received technical regulations from the Latvian natural gas distribution system operator to make a connection to the natural gas distribution system in Riga. In order to make a connection, the LNG terminal operator was obligated to build the following elements of infrastructure and technical equipment: supply pipeline from the terminal to the distribution system, a gas connection point and a metering station with a gas chromatograph [14].

The expected business areas of the terminal were outlined as follows: bunkering, trade of LNG, including deliveries to road transport filling stations and alternative distribution networks, and injection of regasified natural gas into the Latvian natural gas distribution network.

So far there are no indications that would signal a possible beginning of construction of the LNG terminal complex in Kundzinsala in foreseeable future. As an alternative, a proposal to construct LNG terminal in Skulte, the Northwestern part of Riga Gulf, emerged. Skulte project was presented as a floating regasification unit without LNG storage tanks, but with a direct pipeline connection to the Incukalns underground gas storage (hereinafter - Incukalns UGS) facility. Unfortunately, this type of LNG terminal is not designed to supply unregasified LNG, which could be transported further by trucks, for example, to liquefied or compressed - liquefied natural gas (hereinafter - L-CNG) filling stations [15].

The Skulte project developers state that the project has unique geographic, economic and technological advantages over any other LNG import terminal proposal of comparable capacity. A fact that LNG cold storage facility, which usually takes up to $70-80 \%$ of LNG import terminal building expenses, is not needed was presented as its obvious strong point. Instead, the developers made an assumption that Incukalns UGS will serve as a permanent storage for all delivered natural gas resources, and direct high-pressure pipeline connection between the storage and the LNG terminal will be built. Therefore, unparalleled flexibility would be provided to all the project, as LNG can be acquired extensively in favourable market conditions on a spot market basis, and stored in the UGS for winter consumption, while the terminal can reduce operation in high price periods.

Despite the fact, that preliminary costs of the project are not yet known, the developers announced, that total estimated investments would be at least 3 times less than for any other LNG terminal type of comparable capacity with LNG cold storage option [16].

It is estimated that, being in full operation, the regasification capacity of Skulte LNG terminal would reach 3 million tons of LNG per annum, and it would be able to receive LNG carriers of significantly various sizes: between 40.000 and $170.000 \mathrm{~m}^{3}$, and unload them in the period of time from 3 to 6 days.

The project is reapplying for the EU Projects of Common Interest (hereinafter PCI) status under the 5th round of the PCI projects to be decided by the European Commission by the end of 2021 and, according to several sources, this may require repurposing of the project to handle not only traditional LNG, but also biomethane and hydrogen as well [17]. The environmental impact of the project is ongoing since December 2018 [16]. 

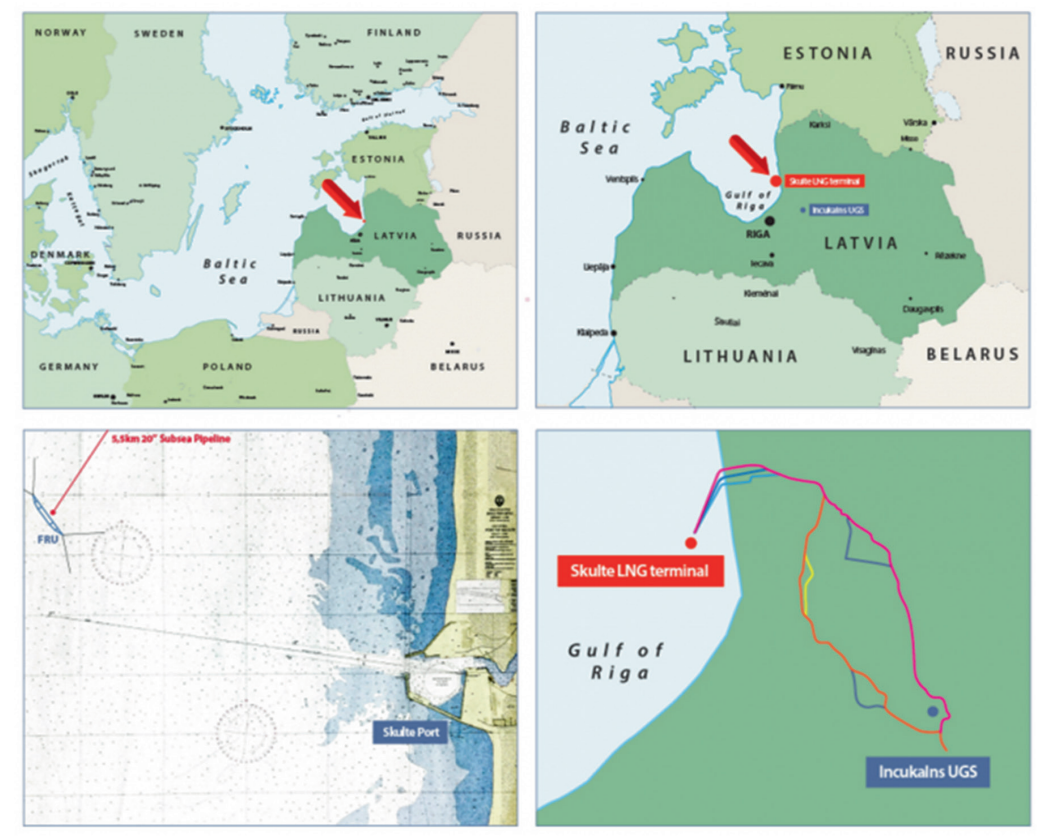

Fig. 3. Proposed location of Skulte LNG terminal with possible pipeline connection routes between it and Incukalns UGS.

Source: skultelng.lv.

Significantly enough, that in 2017, as a part of the Baltic Energy Market Interconnection Plan (hereinafter - BEMIP), the regional natural gas transmission system operators jointly completed the development of the third Gas Regional Investment Plan (hereinafter - GRIP), providing unified information on the planned projects in

\subsection{Estonia}

Estonia, like Latvia, does not have its own LNG import facility, but Port of Tallinn authority is considering the possibility of building the LNG receiving terminal at a location in either Muuga Harbour or Paldiski South Harbour [18]. The purpose of the LNG terminal would be to receive LNG from carrier ships, store it in storage tanks, vaporise, and then deliver the natural gas to a high-pressure distribution pipeline or to the local major natural gas consumers.

Tallinn LNG terminal in particular the BEMIP region. In this plan, the following LNG terminal projects are said to be implemented in the Eastern Baltics: construction of the Paldiski and Tallinn LNG terminals in Estonia, and acquisition of Klaipeda LNG terminal [18], [19]. At the same time, GRIP includes none of potential LNG import terminal projects from Latvia.

would be designed as truck loading, security of supply and bunkering terminal at Muuga harbour with an initial LNG storage capacity of $4000 \mathrm{~m}^{3}$, truck loading rack and up to $0.5 \mathrm{BCM}$ per annum connection to the natural gas grid through a connection point located about $1 \mathrm{~km}$ from the terminal. The terminal would be connected to an existing berth.

There is also a possibility to expand the terminal into an on-land break bulk facility that can service any ship on the market by 
constructing up to four vertical LNG storage tanks with a storage capacity from 50000 to $250000 \mathrm{~m}^{3}$, connecting to a second berth and expanding the natural gas grid connec-

\subsection{Bunkering Activities}

According to consulting company "DNV GL", there were 177 LNG-powered vessels in operation worldwide in 2020. By 2027, another 208 vessels using this type of fuel are expected to be built. The highest concentration of such ships is currently recorded in the North and Baltic Seas. Thus, bunkering is a fast growing and attractive business opportunity, which is also welcomed by the Baltic ports, and particularly Port of Klaipeda. The port conducted its first LNG bunkering operation on 8 March 2020 , with supply of LNG to a cement carrier from the Malkos Bay Terminal [21]. In addition, on 7 January 2019, the world's largest LNG transportation and bunkering vessel "Kairos" was launched. Its main activity in the port of Klaipeda is moving LNG from the terminal to the LNG reloading station situated next to the gates of the port [22]. tion up to $4 \mathrm{BCM}$ per annum through connection into the high-pressure grid located about $13 \mathrm{~km}$ from the terminal [20].

On 14 January 2021, the fourth load of approximately $3000 \mathrm{~m}^{3}$ of LNG arrived at the "Klaipedos Nafta" reloading station, but the previous three loads were delivered in June, August and November 2020, respectively [23]. Since April 2020, the reloading station is almost exclusively used for operations of the Polish energy company PGNiG. In total, since beginning of its bunkering operations, more than 4000 tons or 250 tank trucks of LNG were loaded in Klaipeda.

Bunkering activities are also carried out in other Baltic countries. For instance, the Estonian natural gas company "Eesti Gaas" - one of the major LNG suppliers and the biggest truck-to-ship bunkering service providers in the Northern Europe - in one month period delivers around 1300 tons of LNG and conducts an average of 65 truckto-ship bunkering operations [24].

\section{LNG INFRASTRUCTURE IN FINLAND}

The construction of Finland's first LNG import terminal, located in the city of Pori, was completed in 2016. Currently, it is in full operation. In addition, the Manga LNG import terminal in the city of Tornio was inaugurated in June 2019. There is also the LNG import terminal under construction in Hamina, which is expected to be ready for commercial operation in the first half of 2021 [25].

Construction of the Pori LNG terminal, amounting to EUR 81 million, began in August 2014, and was completed in September 2016, but the first load of LNG arrived there in July 2016. The Ministry of Economic Affairs and Employment of Finland provided EUR 23 million funding for the terminal project. The EC approved the funding under the EU state aid rules in September 2015 [25].

The terminal consists of an LNG tank (height $35 \mathrm{~m}$, outer diameter $42 \mathrm{~m}$ ), loading docks, process units - compressor and vaporizers -, flare torch (height less than $50 \mathrm{~m}$ ), three loading docks for road tankers, transformer building, and heat production unit. The terminal has LNG storage capacity of approximately $30.000 \mathrm{~m}^{3}$. The LNG 
deliveries to industrial customers are made through the local natural gas distribution network, by sea in bunkering vessel or by trucks. Ship-to-ship bunkering operations are available at Pori LNG terminal. There is also a $12 \mathrm{~km}$ long natural gas pipeline that connects the terminal to the local Industrial Park. Construction of the pipeline, which passes through roads, railways and the seabed, began in early August 2015. A $3.2 \mathrm{~km}$ section of the pipeline was laid under the sea, and trenching and pipe-laying works presented multiple challenges due to complicating environmental conditions [26].

Tornio Manga LNG terminal at Röyttä port, Tornio, is the second LNG import facility built in Finland. It is a result of cooperation of several large-scale industrial and energy companies, such as Outokumpu, Ruukki Metals, EPV Energy and Gasum. The companies agreed on the LNG import project to deliver the natural gas to industrial consumers, energy producers and shipping businesses in the North of Finland, where pipeline naturas gas is not available. At the period of construction, it was the largest such facility in the Nordic region with a logistics chain developed around the terminal to create a diversified fuel market benefiting both northern Finland and Sweden [27].

With construction cost of about EUR 100 million, the terminal has complete unloading, storage, pipeline distribution, regasification, truck loading, and ship bunkering facilities. The terminal supplies natural gas to Outokumpu's Tornio steel mill and LNG to local industries, mines, and other consumers in the region. LNG from the terminal will also be supplied to the LNG storage facility at the SSAB Raahe steel mill [28], [29]. From the second half of 2020, Gasum begun delivery of LNG to Eastman Chemical Company in Oulu, as well. The LNG deliveries are carried out by tanker trucks, and the company's switch to usage of LNG is part of the regional commitment to environmental sustainability [30].

Finland's third LNG terminal - Hamina LNG - is currently under construction at the Hamina Harbour, Kotka. Unlike Pori and Tornio terminals, it will be connected to the natural gas transmission system of Finland and to the local natural gas distribution networks. Therefore, Hamina LNG will provide the Baltic-Finnish natural gas market with a new natural gas physical delivery point. It is estimated that the terminal will be in commercial operation by mid-2021.

The storage capacity of the Hamina LNG terminal will initially be $30.000 \mathrm{~m}^{3}$, with a possibility of upgrade by additional $20.000 \mathrm{~m}^{3}$. Its entry capacity into the transmission system as well as into the local distribution system will be 0.5 million $\mathrm{m}^{3}$ per day [25]. It is estimated that approximately 20 ships per year will deliver LNG to Hamina, with a single ship carrying from 5.000 to $25.000 \mathrm{~m}^{3}$ of $\mathrm{LNG}$.

The Ministry of Economic Affairs and Employment of Finland provided EUR 27.7 million co-funding for the construction of Hamina LNG terminal [31].

\section{PROSPECTS FOR THE USE OF LNG IN THE EASTERN BALTICS}

For the Baltic States and Finland alike, prospects for the use of LNG can be linked to the following activities: usage of LNG as maritime and road transport fuel, future utilisation of LNG infrastructure for transportation of liquefied biomethane (hereinafter - LBG) and, possibly, other RG, and usage of LNG in energy generation (as an 
alternative to fossil fuels with more significant GHG emission intensity).

Directive 2014/94/ EU of the European Parliament and of the Council of 22 October 2014 on the deployment of alternative fuels infrastructure (hereinafter - Directive 2014/94/EU) defines a common framework of measures for the deployment of alternative fuels infrastructure in the EU in order to minimise dependence on oil and to mitigate the environmental impact of transport. It sets out minimum requirements for the building-up of alternative fuels infrastructure, including LNG stations with non-discriminatory access for LNG fuelled vessels and road vehicles. According to the Directive, a core network of refuelling points for LNG at maritime and inland ports should be available at least by the end of 2025 and 2030, respectively. Refuelling points for LNG include, inter alia, LNG terminals, tanks, mobile containers, bunker vessels and barges.

Though in the aquatory of the North Sea LNG import terminals are widely spread, the Baltic ports are still struggling to catch up. The LNG terminal development seems favourable for the Eastern Baltics - the Baltic States and Finland, as they will provide decreasing energy dependency by increasing gas supply diversification. Moreover, LNG terminals provide regional shipping with an alternative type of low-emission marine fuel and, in general, with increasingly diverse natural gas supply routes and sources. Among others, Directive 2014/94/ EU obligates the EU Member States to make available bunkering infrastructure for LNG in their territory and allows for their funding through the Connecting Europe Facility instruments [32].

Table 2. Types of Alternative Fuels and their Use

\begin{tabular}{|c|c|c|c|c|c|c|c|c|c|c|c|c|}
\hline \multirow[t]{2}{*}{ Fuel } & \multirow{2}{*}{$\begin{array}{c}\text { Type } \\
\text { Distance } \\
(\mathrm{km})\end{array}$} & \multicolumn{3}{|c|}{ Passenger cars } & \multicolumn{3}{|c|}{ Heavy-duty vehicles } & \multirow{2}{*}{$\begin{array}{c}\text { Air } \\
\text { trans- } \\
\text { port }\end{array}$} & \multirow{2}{*}{$\begin{array}{c}\text { Rail } \\
\text { trans- } \\
\text { port }\end{array}$} & \multicolumn{3}{|c|}{ Shipping } \\
\hline & & $\begin{array}{c}\text { Less } \\
\text { than } \\
150\end{array}$ & $\begin{array}{l}\text { Less } \\
\text { than } \\
300\end{array}$ & $\begin{array}{c}\text { More } \\
\text { than } \\
300\end{array}$ & $\begin{array}{c}\text { Less } \\
\text { than } \\
150\end{array}$ & $\begin{array}{c}\text { Less } \\
\text { than } \\
300\end{array}$ & $\begin{array}{c}\text { More } \\
\text { than } \\
300\end{array}$ & & & Inland & $\begin{array}{l}\text { Short } \\
\text { route }\end{array}$ & $\begin{array}{l}\text { Long } \\
\text { route }\end{array}$ \\
\hline \multirow{2}{*}{$\begin{array}{l}\text { Natural } \\
\text { gas }\end{array}$} & LNG & $\mathbf{X}$ & $\mathbf{X}$ & $\mathbf{X}$ & $\mathbf{X}$ & $\mathbf{X}$ & $\mathbf{X}$ & & $\mathbf{X}$ & $\mathbf{X}$ & $\mathbf{X}$ & $\mathbf{X}$ \\
\hline & $\mathrm{CNG}$ & $X$ & $\mathrm{X}$ & $X$ & $X$ & $X$ & & & & & & \\
\hline \multirow{2}{*}{$\begin{array}{l}\text { Bio- } \\
\text { methane }\end{array}$} & LBM & $\mathbf{X}$ & $\mathbf{X}$ & $\mathbf{X}$ & $\mathbf{X}$ & $\mathbf{X}$ & $\mathbf{X}$ & & $\mathbf{X}$ & $\mathbf{X}$ & $\mathbf{X}$ & $\mathbf{X}$ \\
\hline & bioCNG & $\mathrm{X}$ & $\mathrm{X}$ & $\mathrm{X}$ & $\mathrm{X}$ & $\mathrm{X}$ & & & & & & \\
\hline Electricity & & $\mathrm{X}$ & $\mathrm{X}$ & & $X$ & $X$ & & & $\mathrm{X}$ & & & \\
\hline Hydrogen & & $\mathrm{X}$ & $\mathrm{X}$ & & $\mathrm{X}$ & $\mathrm{X}$ & & & $\mathrm{X}$ & $\mathrm{X}$ & $\mathrm{X}$ & \\
\hline
\end{tabular}

In comparison with traditional fossil fuels such as heavy fuel oil, the use of LNG releases less $\mathrm{CO}_{2}$, no sulphur oxide (hereinafter - $\mathrm{SO}_{\mathrm{x}}$ ), particulate matter and nitrogen oxide, and helps improve air quality. In future, LNG infrastructure can be utilised for import and distribution of LBG, which is a completely renewable energy source that reduces $\mathrm{CO}_{2}$ emissions by as much as $85 \%$ compared to traditional fuels.

\subsection{LNG in Maritime and Road Transport}

The EU has strived for an active role in tackling maritime emissions, both at home and globally. In 2018, the International
Maritime Organization (hereinafter - IMO) agreed to reduce GHG emissions from shipping by at least $50 \%$ in 2050 . The EU and 
its Member States play an instrumental role in brokering and securing the deal for the sector, which currently represents $2-3 \%$ of global $\mathrm{CO}_{2}$ emissions. Discussions are already ongoing at the IMO to translate this deal into concrete measures [33].

In Europe, the choice of location for the LNG bunkering terminals depends on two major factors: firstly, the location of potential clients and, secondly, the suitable areas for building a terminal. LNG is considered an alternative fuel mainly for ships operating in liner service. Hence, LNG terminals for bunkering purposes should be constructed in locations where there are the most density of liner services.

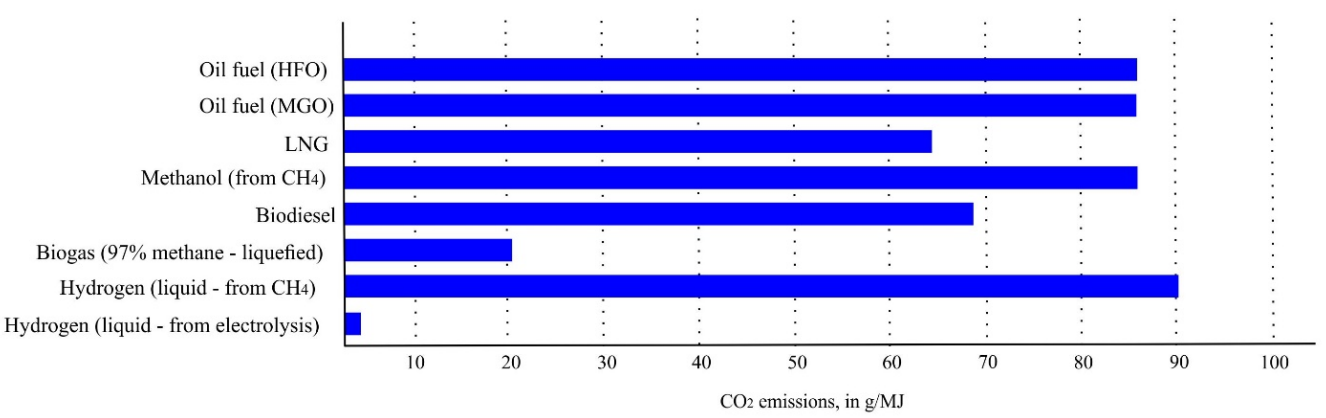

Fig. 4. $\mathrm{CO}_{2}$ emissions for different types of fuel in shipping.

However, at the same time, choice must be guided by a coastal environmental situation, too, as maritime transport has a direct impact on air quality in many European seaside cities. Exhaust gases from ships are a significant source of air pollution, including $\mathrm{SO}_{\mathrm{x}}$ emissions, which are extremely harmful to the human respiratory system. Ships traditionally use fuel oils for propulsion, which can have a sulfur content of up to $3.50 \%$. For comparison, the sulfur content of fuels used in trucks or passenger cars must not exceed $0.001 \%$.

The 2012 Sulphur Directive, which was revised in 2016 [34], reduced $\mathrm{SO}_{\mathrm{x}}$ emissions by setting maximum sulfur content levels for marine fuels and incorporated new standards set by IMO into the EU legislation both inside and outside protected areas. In 2016, the IMO maintained 2020 as entry-into-force date of the global $0.5 \%$ $\mathrm{SO}_{\mathrm{x}}$ cap [33].

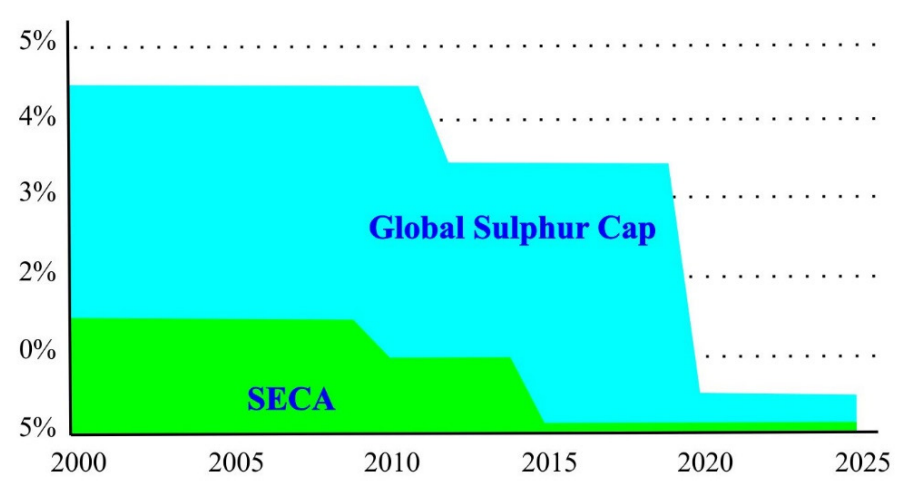

Fig. 5. IMO Sulphur Limits (2000-2025, in \%). 
However, in some very fragile ecosystems such as the Baltic Sea and the North Sea - designated as "Sulphur Oxides Emissions Control Areas" (hereinafter - SECA) the maximum $\mathrm{SO}_{\mathrm{x}}$ content has been reduced to $0.10 \%$ already in 2015 . Such stricter $\mathrm{SO}_{\mathrm{x}}$ limits have more than halved $\mathrm{SO}_{\mathrm{x}}$ concentrations around SECAs, bringing health benefits to people in coastal regions and ports, while the overall economic impacts on the sector remained minimal [35], [36]. A study on the human health impacts of $\mathrm{SO}_{\mathrm{x}}$ emissions from shipping, submitted to IMO's Marine Environment Protection Committee in 2016 by Finland, estimated that by not reducing the $\mathrm{SO}_{\mathrm{x}}$ limit for ships from 2020, the related air pollution would contribute to more than 570.000 additional premature deaths worldwide in next five years [37].

The Baltic Sea as one of the Europe's SECA areas also has good prospects to LNG use as a viable alternative maritime fuel. Moreover, the Baltic maritime trade and passenger ferry routes are quite compact, so different types of ships can be used with rather small fuel capacities, as refueling can be done both en route to next destination and in port of departure or arrival. Along with electric or hydrogen-powered ships, LNG ferries and transport vessels would contribute significantly to reduction of GHG emissions in the Baltic Sea aqua- tory in this decade. It is estimated that till 2040, LNG will play an important role in diversification of the maritime fuel portfolio in all regions of the EU. However, to achieve such a diversification in the Eastern Baltics, more active actions should be taken by the state, local authorities, and businesses.

Current energy consumption in the EU transport sector depends on oil fuels by $94 \%$. This dependency, among other problems, results in high levels of GHG emissions, which, consequently, triggers the necessary to increase the use of less polluting and more cost-effective alternative sources as natural gas. For instance, in comparison with diesel heavy-duty vehicles, LNG fuelled heavy-duty vehicles reduce GHG emissions up to $20 \%$ per kilometre. They also eliminate $100 \%$ of $\mathrm{SO}_{\mathrm{x}}$ and particulate matter emissions, and help reach significant noise level reduction in densely populated areas [38].

Despite an increase in registrations in recent years, alternatively powered passenger cars in the EU make up only about $4 \%$ of the total car fleet [39], [40]. In addition, the European consumption of natural gas in the transport sector is also quite low, amounting to less than $1 \%$ of its total natural gas demand and to a bit more than $2 \%$ of all vehicles on the road today [41], [39], [42].

Table 3. Road Vehicles by Fuel Types in the EU* (2018; \%)

\begin{tabular}{|l|c|c|c|c|c|c|}
\hline Type of Vehicle & Gasoline & Diesel & $\begin{array}{c}\text { Hybrid } \\
\text { Electric }\end{array}$ & Electric** & $\begin{array}{c}\text { CNG, } \\
\text { LNG, LPG }\end{array}$ & Other \\
\hline Passenger cars & 54 & 41.9 & 0.7 & 0.2 & 2.8 & 0.3 \\
\hline Light commercial vehicles & 7.1 & 91.2 & 0 & 0.3 & 1.3 & 0.1 \\
\hline $\begin{array}{l}\text { Medium and heavy-duty } \\
\text { commercial vehicles }\end{array}$ & 1 & 98.3 & 0 & 0 & 0.4 & 0.2 \\
\hline Buses & 0.8 & 95.4 & 0.3 & 0.3 & 2.7 & 0.4 \\
\hline
\end{tabular}

* - including the United Kingdom

* - battery electric + plug-in hybrid

Source: ACEA Report Vehicles in use, Europe 2019 
At the same time, natural gas and other gases, both in the compressed and liquified states, are considered one of the most important elements of the European road transport decarbonisation path. By law, they are regarded as part of "alternative fuel" scope. According to Article 2 (1) of Directive 2014/94/EU, "alternative fuels" are sources of fuel or energy, which at least partially replace fossil fuel oil sources in vehicle power supply and which have the potential to contribute to decarbonisation of transport and the environmental performance of the transport sector. It defines, inter alia, the following alternative fuels: electricity, hydrogen, liquid biofuels (biodiesel, bioethanol and hydrogenated vegetable oil), biomethane, compressed natural gas (hereinafter-CNG) and LNG. It should also be pointed out that $\mathrm{CNG}$ and LNG can originate from various sources - both conventional natural gas and biogas - upgraded till the biomethane level. From the chemical standpoint, natural gas and biomethane are practically identical.

In the Baltic States and Finland, the percentage of alternatively fuelled road vehicles remain rather low, with the natural gaspowered road vehicle fleet in Latvia being equal to about a few hundred. Currently there are only two LNG filling stations in the Baltic States, both located in Estonia, and 9 filling stations located in Finland. It is important to mention that most of these filling stations can serve both CNG and LNG fuelled vehicles. L-CNG filling stations allow filling CNG for light and LNG for heavy-duty vehicles. Such filling stations have lower capital and operating costs than separate LNG and CNG filling stations of similar capacity [43]. LNG is used as a raw material in L-CNG filling stations, and it is stored at a very low temperature: about -163 ${ }^{\circ} \mathrm{C}$, at a pressure of 1 bar. 1 litre of LNG at a pressure of 1 bar contains about 600 litres of natural gas. The type of CNG and LNG combined station is very advantageous in case if there is no natural gas grid access nearby [44].

L-CNG filling stations are advantageous for several reasons, as they:

- allow expanding the network of alternative fuel filling stations throughout the Baltic region and Finland;

- allow setting up natural gas based multifuel type filling stations in places, where pipeline natural gas is not available, or construction of corresponding infrastructure is not financially feasible;

- expand potential availability of RG, firstly and foremostly, LBM [44].

As for the beginning of 2021, there were four public CNG filling stations, one closed filling station and three natural gas filling points available in Latvia. A study by the Ministry of Transport on the Development of Alternative Fuels concludes that the natural gas, including $\mathrm{CNG}$ and $\mathrm{LNG}$, will be a transition fuel in a way to transport sector decarbonisation. Thus, in next fifteen years, according to the most ambitious scenario of the gas filling station expansion along the Latvian natural gas distribution network, 172 CNG (69 of them along Core TEN-T network roads in 9 municipalities) and 6 LNG stations could be installed [45]. It is highly likely that at least some of these stations would be suitable to serve CNG and LNG simultaneously.

According to the most optimistic estimates of the alternative fuel development in Latvia as a whole, by $2050 \mathrm{CNG}$ and LNG will account for more than any other transport fuel in fleet, including diesel and gasoline, but for fulfilment of such a high ambition much stronger and politically coordinated support of RE industry, firstly and foremostly domestic biomethane production and use, is necessary [46]. 


\subsection{LBM and LNG in Energy Generation}

The statistics show that the dynamics of the biomethane production with its subsequent conversion into LBM has demonstrated a significant upward pattern between 2018 and 2020. In this period, a number of biomethane plants in the EU have increased by $51 \%$, from 483 in 2018 to 729 in 2020. There are currently eighteen countries producing biomethane in Europe, with Germany having the highest share of biomethane production plants (232), followed by France (131) and the UK (80) [47].

In the Baltic States, upgrading of the biogas to biomethane level with subsequent injection into the natural gas transportation or distribution grids is not developed yet. However, at least Latvia with 59 existing biogas plants and 17 of them being located 10 or less km away from the natural gas distribution grids could benefit both from biomethane production and local sales (where CNG filling stations and/or small-scale biomethane liquifying facilities are installed onsite) and injection of the biomethane into the natural gas networks [40].

Moreover, in this decade the EU production of LBM is set to increase by factor of ten. The EU LNG heavy-duty transport is expected to reach 280.000 units in the same period. Using a $40 \%$ LBM mix with LNG will help reduce the $\mathrm{CO}_{2}$ emissions from those trucks by $55 \%$. In the shipping sector, $50 \%$ of large container vessel orders today are LNG fuelled or ready for conversion to LNG. $20 \%$ of LBM mix in maritime transport would reduce $\mathrm{CO}_{2}$ emissions by up to $34 \%$.

But, as it was stated before, a tandem of the natural gas and biomethane could be named as one of the most promising midterm transport decarbonisation solutions in the Baltic States and Finland as well. LBM can be transported using the existing LNG infrastructure with no further technological adaptations or additional costs. For this reason, the support of LNG infrastructure is fundamental to ensure the deployment of LBM in the coming years. Today, the EU has 53 ports where LNG bunkering is available and over 330 LNG filling stations, and the number of filling stations is meant to increase sixfold, reaching 2000 by 2030 .

The use of the current LNG infrastructure will also boost cross-border trade of LBM in Europe [48].

In addition to its conventional role in the natural gas market, LNG may also be an energy source for power generation. Power generation from LNG is partially used to maintain the regasification at the $\mathrm{LNG}$ receiving terminals, as these processes are rather energy demanding. The basic thermodynamic processes used in power generation from LNG are: the direct expansion of the regasified and pressurized natural gas, the Rankine cycle and Brayton cycle with use of an auxiliary fluid which expands and propels the turbine. For the pressures up to 3 Megapascals, the suitable option for power generation is simple Rankine cycle and Brayton cycle, for higher pressures the direct expansion of regasified LNG or other complex processes based on modified Rankine or Brayton cycles should be considered [49].

In the Baltic region, use of $\mathrm{LNG}$ in power generation is a viable energy transition option, which might prove itself suitable while supporting Finland's gradual elimination of coal, lignite and, possibly, peat in its power generation sector. If $\mathrm{CO}_{2}$ intensity of the natural gas and coal (hard coal), lignite and peat is compared, it is obvious that natural gas contributes to almost $50 \% \mathrm{CO}_{2}$ emission cut. Namely, $\mathrm{CO}_{2}$ intensity of hard coal is about $0.34 \mathrm{~kg}$ of $\mathrm{CO}_{2}$ per kilowatt- 
hours (hereinafter $-\mathrm{kWh}$ ), the intensity of lignite and peat: $0.36-0.41$ and $0.38 \mathrm{~kg}$ of
$\mathrm{CO}_{2} / \mathrm{kWh}$, but the intensity of natural gas $0.20 \mathrm{~kg}$ of $\mathrm{CO}_{2} / \mathrm{kWh}$ of energy generated.

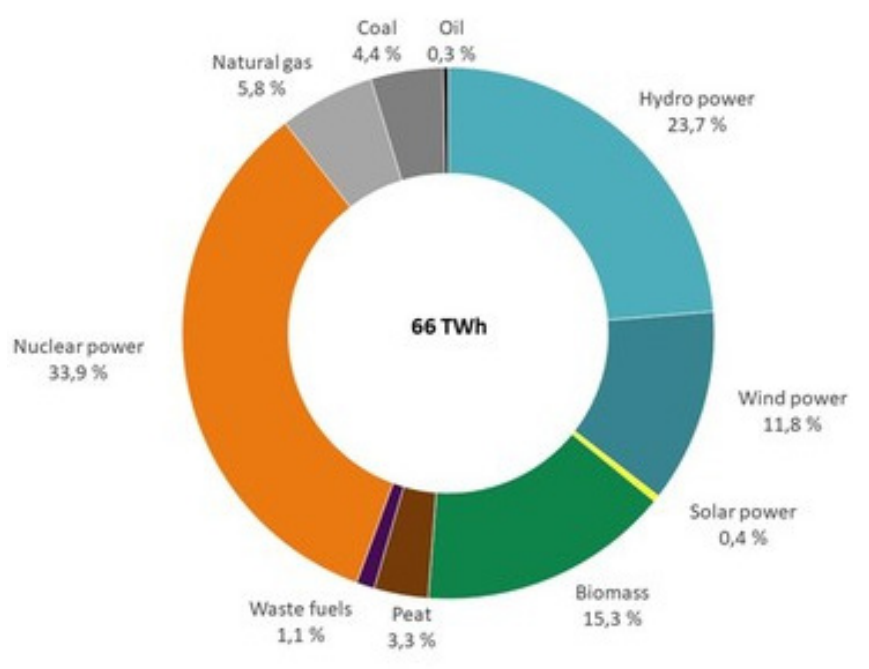

Fig. 6. Electricity production in Finland (2020, by source in \%).

Source: energia.fi.

LNG is suitable for large- and smallscale power generation: both in cogeneration and condensation cycles. For example, from 66TWh of electricity produced in Finland last year, coal contributed to $4.4 \%$, peat - to $3.3 \%$, but natural gas - to $5.8 \%$. If at least a half of energy generated from coal in future comes from natural gas - including LNG-based generation, it will mean that an increase in "the natural gas electricity" will be able to reach $1.9 \mathrm{TWh}$, with associated $\mathrm{CO}_{2}$ emission dropping by almost a half.

\section{CONCLUSION}

The Baltic States and Finland currently have three operational LNG terminals, and one more terminal is about to come online later this year. Two out of three terminals are located in the Northern part of Finland and lack connection to the Finnish national natural gas grids and, therefore, common Baltic-Finnish natural gas market. It makes Klaipeda LNG terminal the only facility in the region, which has such a connection, and can play its role in the market.
The situation, however, is about to change at least from the formal standpoint, as Hamina LNG terminal will soon become the second LNG terminal in the Eastern Baltics to possess an ability to participate in the natural gas market in a capacity of a brand-new natural gas supply route.

Currently the Baltic-Finnish natural gas market shows signs of relative stability, and the gradual switch from the pipeline natural gas to LNG might be expected in 
the mid-time perspective. The role of LNG is expected to grow both in maritime and road transport of the Eastern Baltics, and its power generation sector - especially, with Finland's transition from usage of coal in electricity and heat generation to another, more environmentally friendly sources. The deadline for coal generation phase-out is May 2029; however, Finnish energy producers can voluntarily make a transition by 2025 [50].

It will open door for another generation technologies and fuel sources, such as LNG and eventually - LNG and LBM mix, to step in. As LNG-LBM mix can be used both in transport and power generation, it is one of the most promising options for energy transition in the Eastern Baltics at a large scale - it will not be limited only to certain areas, where natural gas pipelines are available, and will bring benefits of gas technology usage to industrial regions with large energy consumption and urge to develop local energy logistic chains [25]. LNG will soon become indispensable in the growing bunkering business niche of the Baltic Sea aquatory. More terminals and more suppliers will mean a more dense market and better offers, both in ship-to-ship and track-toship bunkering segments.

In the road transport, wider coverage of L-CNG fuelling stations will bring extra profit to fuel retailers, and ensure an ever-expanding network of alternative fuel access points across the Baltic States and Finland. It would help cover the areas of four countries, where natural gas grids are not available, but $\mathrm{CNG}$ and $\mathrm{LNG}$ vehicles need to be fuelled anyway. But in regions, where biomethane production will develop, bioCNG and small-scale LBM fuelling stations and facilities can emerge as part of an alternative gas infrastructure for road transport fuelling.

The development of LNG import terminals of any kinds is the hardest thing to predict in the Eastern Baltics. Despite the fact that several projects in Latvia and Estonia are at different stages of planning, soon completion of at least one of them is rather questionable, and subject to further clarification.

\section{ACKNOWLEDGEMENTS}

The research has been supported by the National Research Programme, project "Trends, Challenges and Solutions of
Latvian Gas Infrastructure Development" (LAGAS) (No. VPP-EM-INFRA-2018/10003).

\section{REFERENCES}

1. Bresciani, G., Heiligtag, S., Lambert, P., \& Rogers, M. (2020). The Future of Liquefied Natural Gas: Opportunities for Growth. [online]. [accessed 1 December 2020]. Available at https://www.mckinsey. com/industries/oil-and-gas/our-insights/ the-future-of-liquefied-natural-gasopportunities-for-growth
2. Nersesian, R. L. (2010). Energy for the 21st century: A comprehensive guide to conventional and alternative sources. M.E. Sharp.

3. Whitney, G., \& Behrens, C. E. (2010). Energy: Natural Gas: The Production and Use of Natural Gas, Natural Gas Imports and Exports, EPAct Project, Liquefied 
Natural Gas (LNG) Import Terminals and Infrastructure Security, Underground Working Gas Storage, Fisher-Tropsch Fuels from Coal, Natural Gas and Biomass, Gas Hydrates, Gas Shales, Hydraulic Fracturing, Alaska Natural Gas Pipelines. The Capitol.Net, Inc.

4. US Office of Fossil Energy. Liquefied Natural Gas (LNG). (n.d.). [online]. [accessed 12 January 2021]. Available at https://www.energy.gov/fe/scienceinnovation/oil-gas/liquefied-natural-gas

5. Swennen, R. (ed.) (2017). China's gas development strategies. Springer.

6. DG Energy. (2020). Quarterly Report on European Gas Markets. [online]. [accessed 5 March 2021]. Available at https://ec.europa.eu/energy/sites/ener/ files/quarterly_report_on_european_gas_ markets_q4_2019_final.pdf

7. EC. (2020). EU-U.S. LNG Trade. U.S. liquefied natural gas (LNG) has the potential to help match EU gas needs. [online]. [accessed 10 January 2021]. Available at https://ec.europa.eu/energy/sites/ener/files/ eu-us_lng_trade_folder.pdf

8. IEA. (2019). The Role of Gas in Today's Energy Transitions. [online]. [accessed 5 February 2021]. Available at https://www. iea.org/reports/the-role-of-gas-in-todaysenergy-transitions

9. Bryden, D., \& Denton, S.-J. (2020). The European Green Deal-Overview and Status Report. [online]. [accessed 25 January 2021]. Available at https://www.lexology. com/library/detail.aspx?g=b18af039-49eb484e-ac52-25820a7513e3

10. EC. (n.d.). What is the European Green Deal? [online]. [accessed 14 January 2021]. Available at https://ec.europa.eu/commission/ presscorner/detail/en/fs_19_6714

11. Hokerts, J. (2020). Gāze - ekoloǵiskiem un ekonomiskiem risinājumiem. In Heat Supply Conference, Riga.

12. Energia Market Research. (2019). Baltic Countries Small-Scale LNG Market Outlook, Trend and Opportunity Analysis, Competitive Insights, Actionable Segmentation \& Forecast 2020-2030. [online]. [accessed 14
January 2021]. Available at https://www. energiasmarketresearch.com/baltic-smallscale-lng-market-report/

13. Gas Processing and LNG. (2020). Lithuania to Import LNG until at least 2044, to Purchase LNG Vessel. [online]. [accessed 10 March 2021]. Available at http://www. gasprocessingnews.com/news/lithuaniato-import-lng-until-at-least-2044,-topurchase-lng-vessel.aspx

14. Gaso. (2019). Kundzinsalas dienvidu projekts. Tehniskie noteikumi.

15. Sināts, M. (2020). Compressed Natural Gas as an Alternative Fuel for Road Transport in Latvia. Master Thesis. Riga: RTU.

16. Skulte LNG Terminal. (2019). [online]. [accessed 3 February 2021]. Available at https://www.skultelng.lv/en/the project/\#i32

17. Summary: Revised TEN-E Regulation Future Financing of European Energy Infrastructure. (2020). [online]. [accessed 16 January 2021]. Available at https:// hsfnotes.com/energy/tag/pcis/

18. Conexus Baltic Grid. (n.d.). Medium-Term Strategy for 2019-2023. [online]. [accessed 9 January 2021]. Available at https://www. conexus.lv/uploads/filedir/Media/conexus mid_term_strategy.pdf

19. GRIP Annex A: Infrastructure Projects. (2017). [online]. [accessed 6 January 2021]. Available at https:/entsog.eu/public/ uploads/files/publications/GRIPs/2017/ entsog_BEMIP_GRIP_2017_Annex_A web.pdf

20. Tallinn LNG. [online]. [accessed 31 January 2021]. Available at https://www.tallinnlng. com/

21. Seatrade Maritime News. (2020). Lithuania's Klaipeda Port Embarks on LNG Bunkering. [online]. [accessed 31 January 2021]. Available at https://www.seatrademaritime.com/bunkering/lithuaniasklaipeda-port-embarks-lng-bunkering

22. World Maritime News. (2019). Nauticor to Become Sole Charterer of LNG Bunker Vessel Kairos. [online]. [accessed 10 February 2021]. Available at https://www. offshore-energy.biz/nauticor-to-becomesole-charterer-of-lng-bunker-vessel-kairos/ 
23. Vessel Finder. (2021). PGNiG Received its Fourth LNG Delivery in Klaipeda. [online]. [accessed 1 February 2021]. Available at https://www.vesselfinder.com/news/19934PGNiG-received-its-fourth-LNG-deliveryin-Klaipda

24. Eesti Gaas. (n.d.). $L N G-$ Clean Fuel with Reasonable Cost. [online]. [accessed 1 March 2021]. Available at https://www. gaas.ee/en/for-business/lng-liquefiednatural-gas/lng-bunkering/

25. Ministry of Economic Affairs and Employment of Finland. (2019). Finland's Integrated Energy and Climate Plan. [online]. [accessed 1 February 2021]. Available at https://ec.europa.eu/energy/ sites/ener/files/documents/fi_final_necp_ main_en.pdf

26. Hydrocarbons Technology. (n.d.). Skangas LNG Import Terminal, Port of Tahkoluoto, Pori. [online]. [accessed 1 February 2021]. Available at https://www.hydrocarbonstechnology.com/projects/skangas-lngimport-terminal-port-of-tahkoluoto-pori/

27. LNG World News. (2019). Manga LNG Inaugurates Tornio Receiving Terminal. [online]. [accessed 10 February 2021]. Available at https://www.offshore-energy. $\mathrm{biz} / \mathrm{manga-lng-inaugurates-tornio-}$ receiving-terminal/

28. Archana Rani, K.S. (2019). Finland Commissions Tornio Manga LNG Receiving Terminal. [online]. [accessed 2 February 2021]. Available at https://www. nsenergybusiness.com/news/finland-torniomanga-lng-terminal/

29. Manga LNG Terminal. (n.d.). [online]. [accessed 5 February 2021]. Available at https://www.torniomangalng.fi/en/ hankkeen-esittely/

30. Gasum. (2020). Gasum Partners with New Customer in Liquefied Natural Gas Deliveries from Manga LNG Terminal in Tornio, Finland. [online]. [accessed 23 January 2021]. Available at https:// www.gasum.com/en/About-gasum/ for-the-media/News/2019/gasumpartners-with-new-customer-in-liquefiednatural-gas-deliveries-from-manga-lngterminal-in-tornio-finland/
31. Mediatiedote. (2020). Tukes has Authorised the Construction of the Hamina LNG Terminal. [online]. [accessed 2 February 2021]. Available at https://tukes.fi/en/-/ tukes-has-authorised-the-construction-ofthe-hamina-lng-terminal

32. Directive 2014/94/EU of the European Parliament and of the Council of 22 October 2014 on the deployment of alternative fuels infrastructure. [online]. [accessed 4 February 2021]. Available at https://eur-lex.europa.eu/legal-content/EN/ $\mathrm{TXT} /$ ?uri $=$ celex\%3A32014L0094

33. EC. (2020.) Cleaner Air in 2020: $0.5 \%$ Sulphur Cap for Ships Enters into Force Worldwide. [online]. [accessed 4 March 2021]. Available at https://ec.europa.eu/ transport/modes/maritime/news/2020-0103-sulphur-cap_en

34. Directive 2016/802/EU of the European Parliament and of the Council relating to a reduction in the sulphur content of certain liquid fuels. [online]. [accessed 4 March 2021]. Available at https://eur-lex.europa. eu/eli/dir/2016/802/oj

35. International Maritime Organization. (n.d.). Emission Control Areas (ECAs) Designated under MARPOL Annex VI. [online]. [accessed 1 March 2021]. Available at https://www.imo.org/en/ OurWork/Environment/Pages/EmissionControl-Areas-(ECAs)-designated-underregulation-13-of-MARPOL-Annex-VI(NOx-emission-control).aspx

36. Damgaard, J. (2020). Low Sulphur Regulations after 1 January 2020. [online]. [accessed 6 January 2021]. Available at https://britanniapandi.com/2020/01/lowsulphur-regulations-after-1-january-2020/

37. International Maritime Organization. (2016). Air Pollution and Energy Efficiency. Study on effects of the entry into force of the global $0.5 \%$ fuel oil sulphur content limit on human health. [online]. [accessed 9 March 2021]. Available at https://wwwcdn. imo.org/localresources/en/MediaCentre/ HotTopics/Documents/Finland $\% 20$ study $\% 20$ on $\% 20$ health $\% 20$ benefits.pdf

38. Osorio-Tejada, J., Llera, E., \& Scarpellini, S. (2015). LNG: Aan Alternative Fuel for 
Road Freight Transport in Europe. [online]. [accessed 1 March 2021]. Available at https://zaguan.unizar.es/record/62843/files/ texto_completo.pdf

39. European Automobile Manufacturers Association. (2018). Vehicles in Use. [online]. [accessed 9 March 2021]. Available at https://www.acea.be/statistics/ tag/category/vehicles-in-use

40. Savickis, J., Zeltins, N., \& Jansons, L. (2019). Synergy between the Natural Gas and RES in Enhancement of Security of Energy Supply in the Baltic Countries (Problem Statement). Latvian Journal of Physics and Technical Sciences, 56 (6), 17-31. DOI: https://doi.org/10.2478/lpts2019-0032

41. ICCT. (2018). European Vehicle Market Statistics, 2018/2019. [online]. [accessed 3 March 2021]. Available at https://theicct. org/sites/default/files/publications/ICCT Pocketbook_2018_Final_20190408.pdf

42. Savickis, J., Zemite, L., Zeltins, N., Bode, I., Jansons, L., Dzelzitis, E., .... \& Ansone, A. (2020). The Biomethane Injection into the Natural Gas Networks: The EU's Gas Synergy Path. Latvian Journal of Physics and Technical Sciences, 57 (4), 34-50. DOI: $10.2478 /$ lpts-2020-0020

43. Sharafian, A., Talebian, H., Blomerus, P., Herrera, O., \& Mérida, W. (2017). A Review of Liquefied Natural Gas Refueling Station Designs. Renewable and Sustainable Energy Reviews, 69 (November 2016), 503-513. https://doi.org/10.1016/j. rser.2016.11.186

44. Reķis, J., Šmigins, R., Gailis, M., \& Klāvs, G. (2018). Pētījums par Eiropas Parlamenta un Padomes 2014. gada 22. oktobra Direktīvas 2014/94/ES par alternatīvo degvielu ieviešanu scenārijiem autotransporta sektorā. 40003142793, 146.
45. Bode, I. (2019). Alternatīvās degvielas izmantošana (presentation).

46. On Alternative Fuels Development Plan 2017-2020. [online]. [accessed 8 March 2021] Available at https://likumi.lv/ta/ en/en/id/290393-on-alternative-fuelsdevelopment-plan-20172020

47. European Biogas Association, Gas Infrastructure Europe. (2020). The European Biomethane Map 2020. [online]. [accessed 3 March 2021]. Available at https://www.europeanbiogas.eu/wpcontent/uploads/2020/06/GIE_EBA BIO_2020_A0_FULL_FINAL.pdf

48. BioLNG Makes Carbon Neutrality a Reality for EU transport. (2020). [online]. [accessed 4 March 2021]. Available at https://www.europeanbiogas.eu/wpcontent/uploads/2020/11/News-Release BioLNG_Paper_EBA-GIE-NGVA-EuropeSEA-LNG-WEB.pdf

49. Franco A., \& Casarosa C. (2014). Thermodynamic and Heat Transfer Analysis of LNG Energy Recovery for Power Production. Journal of Physics: Conference Series, 547

50. Ministry of Economic Affairs and EmploymentofFinland.(2020).InvestmentIncentives to Promote Rapid Phase-Out of Coal in Energy Production. [online]. [accessed 9 January 2021]. Available at https:// valtioneuvosto.fi/en/-/1410877/asetuksellainvestointikannuste-hiilen-energiakaytostaripeasti-luopuville 